\title{
Academic Mapping and Selection of Junior High School Students in West Jakarta
}

\author{
Sri Mugiyati* , Rina Febriana, Guspri Devi Artanti \\ Technology and Vocational Education, Universitas Negeri Jakarta, Indonesia \\ "Corresponding author. Email: smugiyati@yahoo.co.id
}

\begin{abstract}
This study aims to see the general distribution of academic ability and the tendency of further study of junior high school students in West Jakarta. This research is ex-post facto with the quantitative descriptive method. The research indicators include academic achievement, most preferred subjects, further studies, aspirations, and education level. The population of the study is grade IX students of public and private junior high schools in West Jakarta. The sample was established using the cluster random sample technique. Descriptive statistical data analysis technique was used to describe the data for each indicator. The results of the study show that (1) academic achievement based on Report Report Value Data Collection System (SIDANIRA) score range of private junior high schools is $70.73-92.23$, and that of state junior high schools is $73.00-87.07$; (2) in terms of the most preferred subjects, $16 \%$ of public junior high school students chose social studies, and $20 \%$ of private junior high school students chose science and English; (3) 68\% of public junior high school students continue to vocational high school (SMK), 73\% of private junior high school students continue to senior high school (SMA); (4) $52 \%$ of public junior high school students aspired to become entrepreneurs, and $60 \%$ private junior high school students aspired to become entrepreneurs; (5) 7\% of the parents' education level of public junior high school students is tertiary education, $35 \%$ of the parents' education level of private junior high school students is tertiary education.
\end{abstract}

Keywords: Academic achievement, aspirations, further studies, parent educational level, preferred subjects.

\section{INTRODUCTION}

Education is a conscious effort made by the government in an effort to improve the quality of human resources. The success of education is focused on achieving student competencies which include knowledge, skills, and attitudes to face the era of the 21 st century education transformation, in which students are required to master various essential life skills, namely learning and innovation skills, skills in using information technology, and life skills to work and contribute to society [1]. Schools must realize the national ideals and educational goals that have been formulated accurately.

The mapping of further studies of junior high school students in this study is a mapping of the interests or attitudes of students' tendencies to focus, pay attention, and feel happy to choose a high school in accordance with what they aspire to after graduating from junior high school. Interest is a a person's desire, which is permanent to direct a certain choice as a need, manifested in concrete actions by seeking information as insight for himself [2].

Students who are following the education process at the junior high school level certainly have aspirations and desires after graduation. They are faced with a choice of high schools (SMA, SMK, MA), Islamic boarding schools, courses, or job. In such a condition, mental readiness and understanding of students' self-competence is required when making decisions for further studies. The ability to truly understand oneself is one of the important factors in 
dealing with various life activities. Selfunderstanding in continuing studies is very important to be understood by each student, because it is a determinant of their future success [3].

One thing that still needs attention for the Indonesian people so far is that student interest in public schools is still high, even though the capacity of public schools is limited, so a selection process is needed. This condition is also experienced in DKI Jakarta as a metropolitan city where all schools are reached by transportation modes with an uneven distribution of the population, and thus it is necessary to have a strategy in accepting new students.

Based on Permendikbud No. 1 of 2021, the selection to enter state vocational high schools has a quota of $50 \%$ for the academic achievement, $5 \%$ for the non-academic achievement, $43 \%$ for the affirmation, and $2 \%$ for the transfer for parents and children of teachers. While the selection for public high schools has a quota of $18 \%$ for academic achievement, $5 \%$ for non-academic achievement, $25 \%$ for affirmation, $50 \%$ for zoning, $2 \%$ for changing assignments for teachers and students [4].

An interesting phenomenon to study is the change in the behavior of junior high school graduates in choosing schools to higher education levels. The interest of junior high school graduates to continue to high school on average decreases by $2 \%$ per year and those who continued to vocational high school on average increases by $18 \%$ annually. Due to high competition in the world of work, many prefer vocational schools that can provide life provisions based on the potential needed by the world of work. [5].

Many factors affect students in choosing further studies, including: academic achievement, preferences in certain fields, aspirations since childhood, and education level of parents [6]. According to Buhler in [3] the junior high school period is a tentative period. The tentative period begins to realize that every child has different desires and abilities. To be able to realize what they aspire to, it can be started from selecting and preparing schools related to their academic potential or achievements, students preferences in certain fields, and parental support.

\section{METHOD}

The research method used is the descriptive quantitative method. The data collection instrument is a closed questionnaire. The data were analysed using the descriptive analysis. This research is ex-post facto
[6]. It was carried out at SMP Negeri 2 and private junior high schools in West Jakarta1 in May 2021 with a sample of 378 students established using the cluster random sampling technique. This research aims to reveal the effect of each factor in further study mapping of students of public junior high schools and private junior high schools. The percentage measurement used the formula:

$$
\begin{aligned}
& P=F / N \times 100 \% \\
& \mathrm{P}=\text { Percentage } \\
& \mathrm{F}=\text { Frequency of each questionnaire answer } \\
& \mathrm{N}=\text { Total number of answers to the questionnaire }
\end{aligned}
$$

\section{RESULTS AND DISCUSSION}

\subsection{Gender}

The distribution of respondents in this study found 378 students, from public junior high schools returned 336 students consisting of: boys who returned 137 respondents and women found 199 respondents while from private junior high schools were 42 students consisting of: boys collected 15 respondents and girls who returned 27 respondents.

\subsection{Favourite Subjects}

Junior high school students aged 12-15 years are in a tentative period where they have various desires or pleasures [3]. From the research data, the preference for subjects for private junior high school students is that $20 \%$ of students choose natural science (IPA) and English as the most preferred subjects, while the preference for subjects for students of state junior high schools shows that $19 \%$ of students chose physical education and health sports (PJOK) as the most preferred subject and $16 \%$ chose social sciences (IPS) as the second favorite subject.

The selection of the preferred types of subjects for state and private junior high school students in West Jakarta 1 is based on research results, the most detailed is for state junior high school students to choose subjects they like for the reasons that it is according to the field to be occupied is as many as $72 \%$, reasons as supporting ideals as many as $25 \%$ and reasons according to parental directions as many as 3\%. For private junior high school students, 55\% of students choose their preferred subjects with reasons according to the field to be occupied, as many as $55 \%$ of the reasons as supporting the ideals and reasons according to parental direction as many as $3 \%$. Based on the data from the research, the 
reasons why state and private junior high school students choose their preferred subjects are the same, namely the reasons according to the field to be occupied even though the percentages are different. The results of a case study by [7] concluded that the reasons that underlie students in choosing majors in SMK are job opportunities, hobbies or the student's own preferences and value considerations, trial and error in the chosen major, and as a medium to obtain a diploma.

\subsection{Academic Achievements}

Academic achievement is one of the dominant factors for continuing studies to a higher level. For students who will choose state vocational high schools, academic achievement is one of the determining factors for acceptance or not as prospective state vocational high school students, because $50 \%$ of prospective state vocational high school students are selected based on the academic achievement path, and there is no zoning path considering the number of schools. State vocational high school in Jakarta is still limited. In contrast to the selection of state senior high schools, the largest percentage is the zoning route, which is $50 \%$ and the achievement path is only $18 \%$. The selection process through the achievement path consists of the academic achievement path and the non-academic achievement path. Academic achievement this year is taken from the average value of report cards from six subjects consisting of: Indonesian, English, natural sciences, mathematics, social sciences and citizenship education subjects from semester 1 to semester 5 known as value.

SIDANIRA (Report Report Value Data Collection System). These SIDANIRA values are used for the selection process at state high schools and state vocational high schools. Based on the source of the principal in the curriculum area of one private junior high school in West Jakarta, the final score of SIDANIRA was 70.73 and the highest was 92.23. In one of the state junior high schools, the final score of SIDANIRA was 73.00 and the highest was 87.07.

Students academic achievement can also be seen from the results of school exams. School test scores are one of the requirements to determine student graduation so that it must be followed by all students. According to Suryabrata (in Nilam and Santika, 2020), academic achievement is the result of learning from a process expressed in quantitative form (numbers) which is specially prepared for the process of evaluating lesson scores, subjects, test scores and so on [8].

Student academic achievement is very diverse. One of the factors that affect academic achievement is student motivation to excel from each student. Chaplin (in Nilam and Santika, 2020) writes that achievement motivation is to achieve success or to get what is one's ultimate goal, one's involvement, one's hope to succeed in a given task, as well as encouragement to face obstacles and complete work effectively [8], quickly, and precisely. To find out how far the students' academic achievement abilities are in taking school exams, the following table presents the average school exams for public and private junior high school students for five subjects consisting of Indonesian, English, natural sciences, mathematics, and social science subjects.

Table 1. Average scores for the 2020/2021 school exams

\begin{tabular}{|l|l|l|l|}
\hline \multicolumn{2}{|l|}{$\begin{array}{l}\text { State Junior High } \\
\text { School }\end{array}$} & $\begin{array}{l}\text { Private Junior High } \\
\text { School }\end{array}$ \\
\hline Subject & Score & Subject & Score \\
\hline $\begin{array}{l}\text { Bahasa } \\
\text { Indonesia }\end{array}$ & 86.7 & $\begin{array}{l}\text { Bahasa } \\
\text { Indonesia }\end{array}$ & 84.2 \\
\hline English & 86.5 & English & 82.2 \\
\hline Science & 82.9 & Science & 84.9 \\
\hline Math & 79.4 & Math & 79.9 \\
\hline $\begin{array}{l}\text { Social } \\
\text { Education }\end{array}$ & 80.2 & $\begin{array}{l}\text { Social } \\
\text { Education }\end{array}$ & 84 \\
\hline
\end{tabular}

Source: vice principal for curriculum

\subsection{Further Study}

Planning for further studies is the students' ability to make decisions about choosing a secondary school to support their goals. This is in accordance with the opinion of Walgito [9] who says that planning further studies is useful for: a) understanding and assessing oneself, especially with regard to the potential that exists in him regarding abilities, interests, attitudes and ideals; b) realizing and understanding the values that exist in themselves and those in society; c) the type of work related to the potential that exists within him, knowing the types of education and training needed for a particular field, and understanding his current relationship with the disclosure period.

Based on the research, further studies of state junior high school students to the senior high school (SMA) were $32 \%$ and direct studies to the vocational 
high school (SMK) level were 68\%. As many as $73 \%$ of private junior high school students choose to continue their study to the high school level and $27 \%$ choose to continue their study to vocational high school (SMK) level. The percentage of the reasons for for state junior high school students in selecting studies are that they want to work immediately as (44\%), continue their studies to universities $(38 \%)$, and that the location of the school is close to their residence $(18 \%)$. The percentage of private junior high school students in the selection of further studies because they want to work immediately is $15 \%, 70 \%$ continue their studies to universities, and the reason that the location of the school is close to where they live is $15 \%$.

There is support from parents of state junior high school students in terms of further studies to senior high school level by $67 \%$ and $33 \%$ not supporting. Meanwhile, support from parents of private junior high school students in terms of further studies to the high school level is $93 \%$ and $7 \%$ do not support. The percentage of reasons why parents of state junior high school students support further study to vocational high school is $59 \%$ with reasons to work immediately and $41 \%$ with reasons to continue to higher education. The percentage of reasons for parents of private junior high school students supporting further studies to vocational high school for reasons of wanting to work immediately is $35 \%$ and for reasons of continuing to college is $65 \%$.

The views of parents and the choice of students to continue to the vocational level are in the hope of working immediately. This is true and in accordance with Handayani's opinion [2] which says that vocational education is special education that is planned to prepare students to enter the world of work and to be able to develop professional attitudes in certain professional fields. Vocational education is programmed to equip students with various knowledge, skills, and attitudes in accordance with the needs of the workforce. According to [5] the orientation of vocational high schools is: (1) providing students with competencies/skills to meet the needs of the job market in the business / industrial world; (2) providing students with competencies/skills to live independently, to develop entrepreneurship, and to create jobs; (3) providing students with academic competence/skills and skills to provide opportunities to continue to a higher level of education, so vocational education emphasizes more on the skills (theory and practice) of students to enter the workforce in the future. Vocational education graduates are expected to become productive humans who are able to create superior products that can compete in the free market and have the opportunity to continue to a higher level. Figure 1 is a more detailed description of the selection of further studies for state and private junior high school students along with the reasons and sources of education costs.

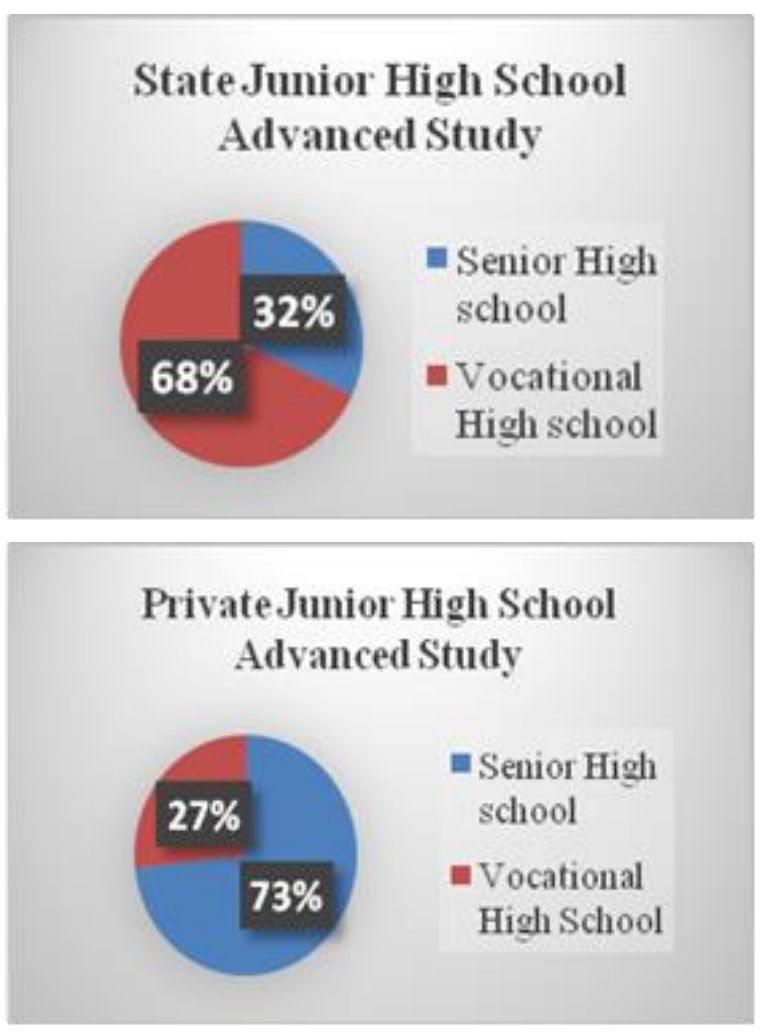

Figure 1 Selection of further studies

\subsection{Goals}

The results show that $60 \%$ of private junior high school students aspire to become entrepreneurs and $40 \%$ aspire to work in an office. As for the state junior high school students, $52 \%$ aspire to become entrepreneurs and the remaining $48 \%$ aspire to work in the office. The ideals to be achieved by state junior high school students, both becoming entrepreneurs and working in offices, are desires that come from encouragement in students, with a percentage of $92 \%$, while the remaining $8 \%$ is encouragement from parents. Likewise, the ideals to be achieved by private junior high school students are desires that come from within the students with a percentage of $95 \%$, the remaining $5 \%$ is encouragement from parents.

Hurlock in [10] defines ideals as the desire to achieve something higher than the current situation. By having the ideals of life, one has a way or direction to reach the future. According to [11] ideals 
can have the effect of high enthusiasm for learning because they will try to realize their goals by studying hard. When they feel tired, lazy, even hopeless, the role of parents is very important to continue to motivate children to remember what they aspire to.

\subsection{Parental Education}

According to [12], parental factors have a very large effect on children's success. The level of education, the size of the income, the sufficient or lack of attention and guidance of parents and children, whether or not parents get along well, whether or not the relationship between parents and children is close, all greatly affect the success of children. The importance of the educational background of parents in educating children shows that the background of parents who are highly educated will increasingly be able to assist the learning process, including how to fulfill facilities and infrastructure in learning so as to help the success of children, in addition to educated parents and they will also look different in directing and guiding children [13].

The results of the research from the indicators of parental education indicate that the educational background of the parents of state junior high school students consists of: (a) fFather's education: college (7\%), high school (48\%), junior high school (26\%), and elementary school (19\%); (b) mother's education: college $(7 \%)$, high school (40\%), junior high school (28\%), and elementary school (19\%).

The results of the research from the indicators of parental education indicate that the educational background of parents of private junior high school students consists of: (a) father's education: college (35\%), high school (58\%), junior high school (5\%), and elementary school (2\%); (b) mother's education: college $(40 \%)$, high school (43\%), junior high school $(10 \%)$, and elementary school $(7 \%)$.

Based on the research data, the educational background of the fathers of private junior high school students with higher education is $35 \%$, while the educational background of the fathers of public junior high school students who have higher education is only $7 \%$. The educational background of the mothers of private junior high school students with tertiary education is $40 \%$, while the educational background of mothers of state junior high school students with tertiary education is only $7 \%$. Parent's education represents the socioeconomic background of the family. High parental education has a high socio-economic level. Students academic achievement is very closely related to their economic condition. The students with a good economy will be able to access better learning resources. Socioeconomic status tends to affect someone to have knowledge and job understanding [3].

\section{CONCLUSION}

There is a difference in the indicators of the most preferred subjects for public junior high school students and private junior high school students. The reasons for the students of public junior high schools and private junior high schools choosing their preferred subjects are the same, namely the reasons according to the field to be occupied.

Academic achievement is one of the main factors in the selection of further studies both at the high school and vocational high school levels.

Further study indicators show that $73 \%$ of private junior high school students want to continue to high school, $70 \%$ want to continue to college, $68 \%$ of public junior high school students want to continue to vocational high school because they want to work.

The ideal indicator shows that almost all junior high school and private junior high school students who want to become entrepreneurs or work in offices are job-oriented students.

The educational background of the parents of private junior high school students at the tertiary level is higher than that of parents of public junior high schools.

\section{ACKNOWLEDGMENTS}

The authors would like to thank their colleague for their contribution and support to the research. This work was supported by Lembaga Penelitian dan Pengabdian Masyarakat (LPPM), Universitas Negeri Jakarta, under Grant Number: 5/PPI/LPPM/IV/2021, April 26, 2021.

\section{REFERENCES}

[1] D. J. Ministry of Education and Culture, guidelines for specification in first middle school," no. 7, pp. 195, 2013.

[2] F. Tanjung, S. Parenrengi, S. M. Moh. Ahsan, Student's interest and motivation to continue study in vocational middle school, department of automotive engineering, Polewali Mandar District, 2019. 
[3] W. Dharmayanti, S. Munadi, Factors that influence the interest of junior high school students to enter SMK in Pontianak city, j. educator. vocational, vol. 4 , no. 3 , pp. 405-419, 2014, doi:10.21831/jpv.v4i3.2563.

[4] Ministry Of Education And Culture, Permendikbud Number 1 of 2021 concerning admission of new students at the kindergarten, elementary, middle, high and vocational levels, permendikbud, pp. 1-25, 2021, [dare]. Available on:

https://lpmpkaltara.kemdikbud.go.id/2021/01/18 /permendikbud-nomor-1-tahun-2021-tentangpenerimaan-peserta-didik-baru-jenjang-tk-sdsmp-sma-dan-smk/.

[5] R. S. T. Dewi, M. A. Masruhim, Study on student decisions to continue study at vocational middle school (SMK) Semarang district, lab. researcher. and development. pharmacy cup. fac. farmland. Univ. Mualawarman, Samarinda, East Kalimantan, no. April, pp. 5-24, 2016.

[6] R. Febriana, D. R. Hidayat, Identification of factors affecting first middle school students ( smp ) in choosing further studies to vocational high school ( vocational school ) in Jakarta Universitas Negeri Jakarta, Indonesia 2 Universitas Negeri Jakarta, Indonesia, abstrak : pen," no. 3 , pp. 7 .

[7] W. I. Suci, Reasons for department selection in vocational middle school students (case study at smk negeri 3 sukoharjo in 2012), 2013.

[8] Santika, Factors affecting student academic achievement, J. Pendidik., vol. 21, no. 1, pp. 117, 2020, doi: 10.33830/jp.v21i1.704.2020.

[9] A. Endriani, Maemunah, Journal of Reality Volume 1 Number 1 April 2016 edition guidance and counseling, FIP IKIP Mataram, vol. 1, no. april, pp. 46-57, 2016.

[10] I. S. P. J. Gulo, Relationship between learning interest, student's aspirations, teacher competency, community of people with the learning motivation of state high school students in Sleman District, 2018.

[11] A. Illyas, A. Aldrian, N. Hidayah, S. B. Kurniati, Pocita: Introducing ideals and the environment from an early age, vol. 3, no. 2, pp. $181-186,2020$.

[12] P. Wibowo, Factors affecting students' interest in choosing to enter vocational high school in industrial electronics expertise program in Kulon Progo Regency, J. Chem. inf. Models, vol. 53, no. 9, p. 1689-1699, 2017.

[13] E. Fitriana, The influence of parents' education level on social studies learning outcomes at SDN Gugus dr. Sutomo Kajen Pekalongan Regency," 2016. 